\title{
Size and Stability of Curcumin Niosomes from Combinations of Tween 80 and Span 80
}

(Saiz dan Kestabilan Niosom Kurkumin daripada Gabungan Tween 80 dan Span 80)

\author{
MASRINA MOHD NADZIR*, TAN WeI Fen \& ABDUl RAHMAN MOHAMED \& Siti FARHANA Hisham
}

\begin{abstract}
The ratios of Tween 80 to Span 80 are important in controlling the physicochemical characteristics of curcumin niosomes. Thus, in this study the correlations of combination of Tween 80 and Span 80 at different ratios with the size and stability of curcumin niosomes were investigated. Initially curcumin was dissolved in chloroform and methanol $(v /$ $v=3: 1)$, followed by the preparation of niosomes by thin-film hydration method with the mole ratio of mixture of Tween 80 and Span 80 to cholesterol of 2:1. The ratios of Tween 80 to Span 80 in the mixture were set at 1:1, 1:9, 9:1, 2:3 and 3:2 with Hydrophilic-Lipophilic Balance (HLB) values of 9.65, 5.37, 13.93, 8.58 and 10.72, respectively. As expected, niosome barely formed at HLB value 13.93. This might be due to the molecule being hydrophilic and well hydrated which inhibits the formation of a stable bilayer in solution. It was found that the formulation which has higher Span 80 and lower HLB value leads to larger niosome before sonication. The largest niosome size achieved from Tween 80 to Span 80 ratio of 1:9 and 2:3 was 77.36 and $59.85 \mu \mathrm{m}$, respectively. On the other hand, for the ratio of 3:2, the largest niosome formed before sonication was less than $50.00 \mu \mathrm{m}$. After sonication, the niosome size reduced to less than $35.00 \mu \mathrm{m}$ for all formulations. It was showed that formulation with Tween 80 to Span 80 ratio of 1:9 has superior curcumin entrapment efficiency and best stability during storage. The results demonstrated that appropriate ratio of Tween 80 to Span 80 was necessary for forming small and stable curcumin niosomes.
\end{abstract}

Keywords: Characterization; curcumin; niosome; non-ionic surfactants

\section{ABSTRAK}

Nisbah Tween 80 kepada Span 80 adalah penting dalam mengawal ciri fizikokimia niosom kurkumin. Oleh itu, dalam kajian ini korelasi gabungan Tween 80 dan Span 80 pada nisbah-nisbah yang berbeza dengan saiz dan kestabilan niosom kurkumin telah dikaji. Sebagai permulaan, kurkumin telah dilarutkan dalam kloroform dan metanol $(v / v=3: 1)$, diikuti dengan penyediaan niosom-niosom melalui kaedah penghidratan filem nipis dengan nisbah mol campuran Tween 80 dan Span 80 kepada kolesterol bernilai 2:1. Nisbah Tween 80 kepada Span 80 dalam campuran ditetapkan pada 1:1, 1:9, 9:1, 2:3 dan 3:2, dengan nilai Imbangan Hidrofilik-Lipofilik (HLB) masing-masing 9.65, 5.37, 13.93, 8.58 dan 10.72. Seperti yang dijangka, niosom hampir tidak terbentuk pada formulasi dengan nilai HLB pada 13.93. Ini mungkin kerana molekul adalah hidrofilik dan terhidrat, oleh itu menghalang pembentukan dwilapisan yang stabil dalam larutan. Didapati bahawa formulasi yang mempunyai kandungan Span 80 yang lebih tinggi dan nilai HLB yang lebih rendah membawa kepada niosom lebih besar sebelum sonikasi. Saiz niosom terbesar yang dicapai daripada nisbah Tween 80 kepada Span 80 bernilai 1: 9 dan 2: 3 masing-masing adalah $77.36 \mu \mathrm{m}$ dan 59.85 нm. Sebaliknya, bagi nisbah 3:2, niosom terbesar dibentuk sebelum sonikasi adalah kurang daripada 50.00 pm. Selepas sonikasi, saiz niosom dikurangkan kepada kurang daripada 35.00 m untuk semua formulasi. Didedahkan bahawa formulasi dengan nisbah Tween 80 kepada Span 80 bernilai 1:9 mempunyai kecekapan pemerangkapan kurkumin yang unggul dan kestabilan terbaik semasa penyimpanan. Keputusan menunjukkan bahawa nisbah Tween 80 kepada Span 80 yang sesuai adalah perlu bagi membentuk niosom kurkumin yang kecil dan stabil.

Kata kunci: Kurkumin; niosom; pencirian; surfaktan bukan ionik

\section{INTRODUCTION}

Curcumin is the major component of naturally occurring yellow-orange pigment in Curcuma longa. This polyphenol is widely research for its anti-tumour, anti-inflammatory, anti-oxidant and wound healing properties (Hussain et al. 2017; Joung et al. 2016; Nagahama et al. 2016; Ratanavaraporn et al. 2017). The administration of curcumin to patients has severe limitations in terms of water solubility at physiological $\mathrm{pH}$ and bioavailability. Drug delivery system (DDS) plays a very important role in overcoming these challenges. Vesicular system with bilayer membrane and hollow space is one of the most attractive DDS because of having longer entrapment storage time, receptive surface for treating various targeting agents, and suitable for delivery of hydrophobic and hydrophilic drugs. Liposome and niosome stand out as the vesicle carrier 
for drugs. However, compared to liposome, niosomes are osmotically active, chemically stable and have long storage time (Marianecci et al. 2014). The two major components used for the preparation of niosomes are cholesterol and non-ionic surfactant. Niosomes prepared with non-ionic surfactant, Tween 20 in combination with cholesterol was reported to suppress the degradation of curcumin better than micelles (Mandal et al. 2013). Tween 80 and Span 80 have been tested in pharmaceutical field as drug delivery system and in particular they can be used to prepare highly stable niosomes (Ruckmani et al. 2000; Yoshioka et al. 1994). There are studies that showed that the combination of Tween and Span type of non-ionic surfactant will actually increase the entrapment efficiency of the niosome ( $\mathrm{Lv}$ et al. 2014). The niosomes obtained from the mixture of Tween 80 and Span 80 were reported to be an effective carrier for topical delivery of capsaicin (Tavano et al. 2011). Furthermore, curcumin encapsulated in niosomes composed of Tween 80, Span 80 and Poloxamer 188 exhibited enhanced cytotoxic activity against ovarian cancer A2780 cells compared with freely dispersed curcumin (Xu et al. 2016). However, to our knowledge, no studies have reported the correlation of Tween 80 to Span 80 ratios on the size and stability of curcumin niosomes.

In this study curcumin niosomes were synthesized using various combinations of Tween 80 and Span 80 . The physicochemical properties in terms of niosome size, curcumin entrapment efficiency and stability during storage were investigated.

\section{MATERIALS AND METHODS}

\section{CURCUMIN NIOSOMES PREPARATION AND SIZE DETERMINATION}

Curcumin ( $\geq 65 \%$ pure), Span 80 and Tween 80 were purchased from Sigma-Aldrich, USA, and used as received. Niosomes were prepared by thin-film hydration method as reported in the literature (Mandal et al. 2013) with some modifications. Initially, non-ionic surfactants and cholesterol (molar ratio $=2: 1$ ) and $0.04 \mathrm{~g}$ curcumin were dissolved in mixture of chloroform and methanol $(3: 1$ $\mathrm{v} / \mathrm{v}$ ) in a round bottomed flask. The organic solvent was removed by using rotary vacuum evaporator (BÜCHI, Switzerland) to form a thin film on the inside wall of the flask. The dried film was then hydrated by addition of 10 $\mathrm{mL}$ of distilled water and vortexed. This was followed by sonication of the dispersion at $60^{\circ} \mathrm{C}$ to reduce the size of niosomes. Finally, the solution was centrifuged at 11,000 $\mathrm{rpm}$ and at $4^{\circ} \mathrm{C}$ to remove free surfactants and larger vesicles. The Tween 80 to Span 80 ratios were set to be 1:1 (Formulation 1), 1:9 (Formulation 2), 9:1 (Formulation 3), 2:3 (Formulation 4) and 3:2 (Formulation 5).

Curcumin niosomes were observed under microscope (Olympus Bx53, Japan) before and after sonication using $100 \times$ objective lens. Captured images were analyzed using $\mathrm{NIH}$ ImageJ to determine the size of niosomes.

\section{CALCULATION OF HYDROPHILIC-LIPOPHILIC BALANCE}

The hydrophilic-lipophilic balance (HLB) values for the formulations were calculated using:

$$
\text { HLB value }=\left[\frac{\left(\mathrm{HLB}_{\mathrm{A}}-\mathrm{HLB}_{\mathrm{B}}\right) \times \mathrm{R}_{\mathrm{A}}}{\left(\mathrm{R}_{\mathrm{A}}+\mathrm{R}_{\mathrm{B}}\right)}\right]+\mathrm{HLB}_{\mathrm{B}}
$$

where $\mathrm{HLB}_{\mathrm{A}}, \mathrm{HLB}_{\mathrm{B}}, \mathrm{R}_{\mathrm{A}}$ and $\mathrm{R}_{\mathrm{B}}$ denote the HLB value of Tween 80 , HLB value of Span 80, ratio of Tween 80 and ratio of Span 80 , respectively.

\section{DRUG ENTRAPMENT EFFICIENCY}

The entrapment efficiency (EE\%) of curcumin in niosomes was determined by centrifuging niosomal dispersion at $11,000 \mathrm{rpm}$ for $60 \mathrm{~min}$ at $4^{\circ} \mathrm{C}$ to remove free curcumin. Niosomes were then re-dispersed in distilled water and centrifuged at the aforementioned conditions. Collected pellets were diluted in $5 \mathrm{~mL}$ distilled water followed by the addition of $5 \mathrm{~mL}$ ethanol. Sample was then vortexed and centrifuged. The supernatant was quantified by UV-Vis spectrophotometer (Thermo Scientific GENESYS 20, USA) at $500 \mathrm{~nm}$. The EE\% was determined using the following formula:

$$
\begin{aligned}
\mathrm{EE} \%= & {\left[\frac{\text { Amount of entrapped curcumin }}{\text { Total curcumin }}\right] \times 100 \% } \\
& \text { STABILITY AND SOLUBILITY TEST }
\end{aligned}
$$

The stability of niosomes was determined by storing it at room temperature, $4^{\circ} \mathrm{C}$ and $-4^{\circ} \mathrm{C}$. Evaluation was conducted on day 3 and day 7 of storage by observation of changes in the structure of niosomes under microscope (Olympus BX53, Japan) and by determining the percentage of remaining entrapped curcumin. The entrapped curcumin (\% Entrapment) was evaluated by initially centrifuging dispersion of niosomes at $11,000 \mathrm{rpm}$ for $60 \mathrm{~min}$ at $4^{\circ} \mathrm{C}$ to remove free curcumin. This was followed by re-dispersing niosomes in $5 \mathrm{~mL}$ distilled water and the addition of $5 \mathrm{~mL}$ ethanol. Sample was then vortexed and centrifuged. The supernatant was quantified by UV-Vis spectrophotometer (Thermo Scientific GENESYS 20, USA) at $500 \mathrm{~nm}$. The \% Entrapment was determined using the following formula:

$$
\begin{aligned}
\% \text { Entrapment }= & {\left[\frac{\text { Amount of entrapped curcumin }}{\text { Amount of entrapped curcumin on day } 0}\right] } \\
& \times 100 \%
\end{aligned}
$$

\section{RESULTS AND DISCUSSION}

It is clearly shown in Figure 1 that large curcumin niosomes could be formed prior to sonication for all of the formulations, with the exception of Formulation 3 . The sonication process resulted in the reduction of niosomes size. Only a few intact niosomes were observed in sample from Formulation 5, indicating that niosomes synthesized using this formulation easily disintegrate when sonicated. The calculated HLB value for Formulations 

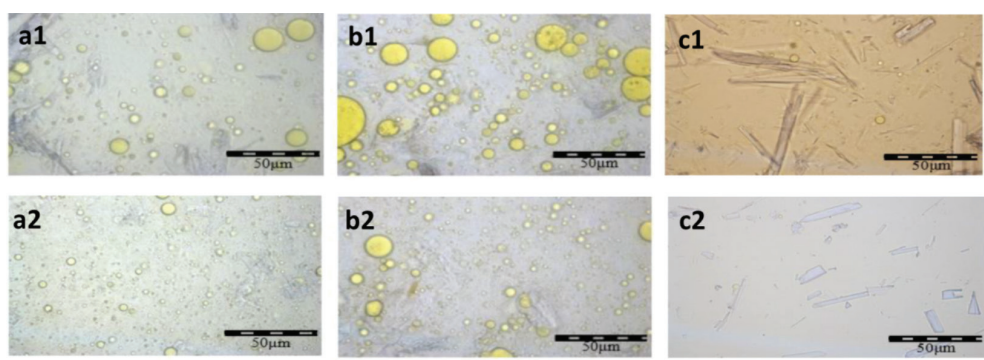
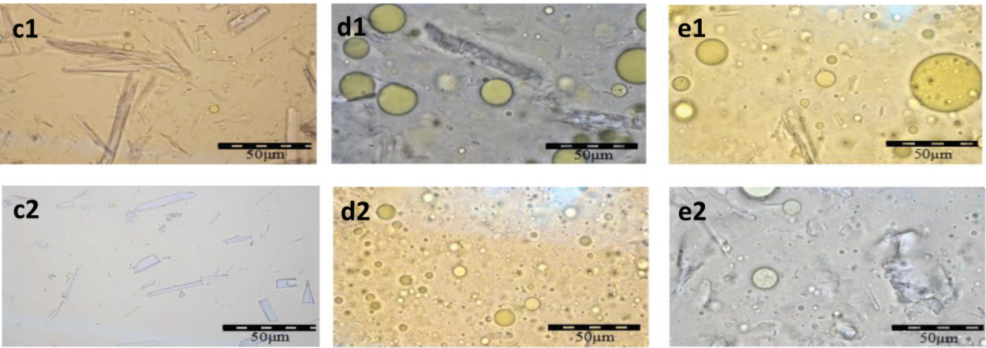

FIGURE 1. Niosomes before sonication for Formulation 1 (a1), Formulation 2 (b1), Formulation 3 (c1), Formulation 4 (d1) and Formulation 5 (e1). The images of niosomes after sonication process are (a2), (b2), (c2), (d2) and (e2) for Formulation 1, Formulation 2, Formulation 3, Formulation 4 and Formulation 5, respectively

$1,2,3,4$ and 5 was $9.65,5.37,13.93,8.58$ and 10.72 , respectively. The inability to form niosome when using Formulation 3 is consistent with what has been reported previously (Biswal et al. 2008; Shahiwala \& Misra 2002), where niosomes did not form at HLB values 14 to 17 . It is known that molecules are hydrophilic and well hydrated at high HLB value. This low hydrophobicity inhibited the formation of stable bilayer in solution. The disintegration of niosomes from Formulation 5 upon sonication shows that the amount of added cholesterol depends on the HLB value and synthesizing process. In this case, increasing the cholesterol concentration in Formulation 5 could result in more rigid niosomes which could withstand the sonication process.

Many large niosomes could be observed in samples from Formulations 2 and 4 (Figures 1 (b1) and (d1)) prior to sonication, indicating that the formulation which have high
Span 80 and lower HLB value could lead to larger niosomes. This is supported by the broad size distribution in Figures 2 (a1-c2), where diameter of niosomes from Formulation 2 before sonication reached $77.36 \mu \mathrm{m}$. Similar results were reported for ellagic acid niosomes (Junyaprasert et al. 2012) and paclitaxel niosomes (Bayindir \& Yuksel 2010), where the sizes of niosomes increased when the HLB values of the surfactant decreased. The higher amount of Span 80 in Formulation 2 and 4 caused the increase in hydrophobicity which in turn decreases the surface free energy (Akhilesh et al. 2012). Although, Tween 80 and Span 80 typically consist of same length of alkyl chain (C18), the hydrophilic head size for Span 80 is smaller compared to Tween 80 . Thus, larger aggregation number was required. In Formulation 2, the composition of Span 80 was dominant hence more small hydrophilic head existed. The smaller hydrophilic to hydrophobic area leads to a

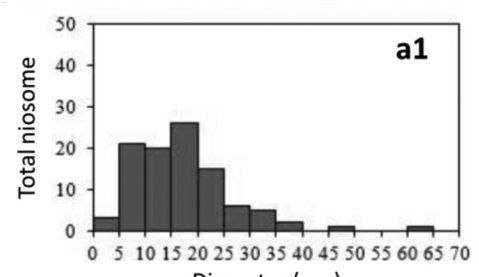

Diameter $(\mu \mathrm{m})$
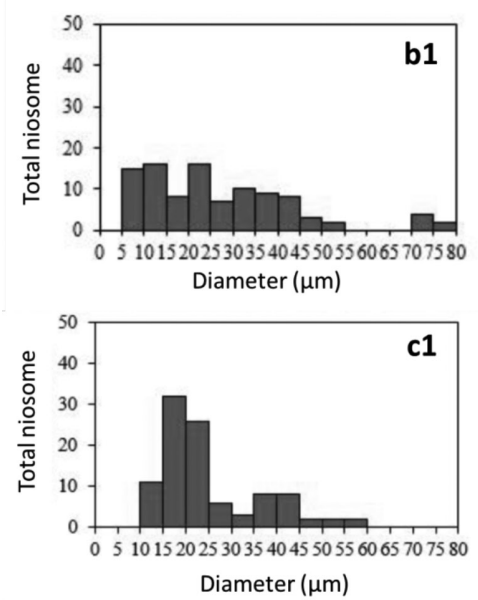
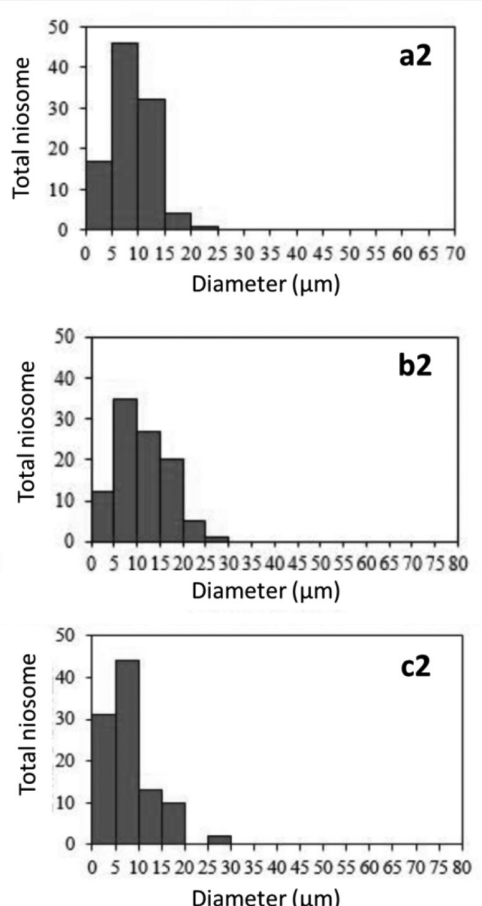

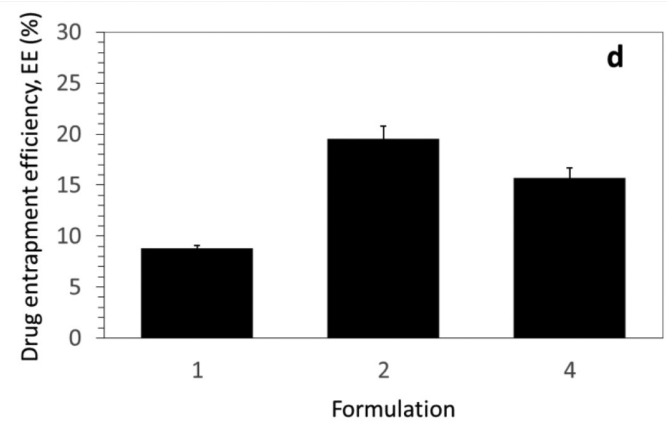

Formulation

FIGURE 2. Size distribution of niosomes before sonication for Formulation 1 (a1), Formulation 2 (b1) and Formulation 4 (c1). The size distribution of niosome after sonication process are (a2), (b2) and (c2) for Formulation 1, Formulation 2 and Formulation 4, respectively. The drug entrapment efficiency is shown in (d) 
thicker bilayer and larger size of vesicle. After sonication, the size of niosomes for all formulations was reduced to more than $50 \%$ with narrow size distribution. Majority of niosomes was found to be in the size range of 5-10 $\mu \mathrm{m}$.

The entrapment efficiency of curcumin niosomes varied between Formulations 1, 2, and 4 (Figure 2d) with Formulation 2 having the highest entrapment efficiency, $19.51 \%$. The particle size correlated with the entrapment efficiency since the entrapment of curcumin increased with the increase in vesicle size. In this study, Formulation 4 has an entrapment efficiency of $15.68 \%$ which was the second highest followed by Formulation 1 which has EE\% of $9.42 \%$. It has been suggested that lower drug entrapment is caused by the presence of unsaturated alkyl chain in Span 80 and Tween 80 (Dharashivkar et al. 2014). Although, the EE\% in this study was lower than the $89.65 \%$ efficiency of curcumin entrapment reported by Rungpanichkul et al. (2011), only Span 80 was used in that study. It is possible that the significant difference in $\mathrm{EE} \%$ between these two studies was due to the loading amount. In the study conducted by Rungpanichkul et al. (2011), it was found that the EE\% increased with increased in loading amount from 4.29 to $8.60 \mu \mathrm{mol}$. In the current study, loading amount of curcumin was set at
$108.58 \mu \mathrm{mol}$. It is possible that niosomes were already saturated with curcumin at lower loading amount and the excess curcumin precipitated due to poor aqueous solubility.

The changes of $\%$ Entrapment were observed to investigate the possibility of curcumin leaching from the niosomes during storage at three different temperatures as shown in Figure 3. Niosomes from Formulations 2 and 4 were found to be more stable compared to Formulation 1 . Storage temperatures did not have any significant effect on the stability of niosomes of these two formulations as only slight difference in reduction of entrapped curcumin could be observed for samples stored at the different temperatures. On the other hand, the stability of niosomes from Formulation 1 was influenced by the storage temperatures, where the decrease of entrapped curcumin was the highest for samples stored at room temperature, indicating leaching. The curcumin leakage at high temperature might be due to the higher fluidity of lipid bilayers at high temperature (Hofland et al. 1992). In addition, disrupted or aggregated niosomes were observed in samples stored at room temperature and $4^{\circ} \mathrm{C}$ (Figure 4). This disruptions or aggregations of vesicles resulted in loss of vesicles could be due to the hydrated
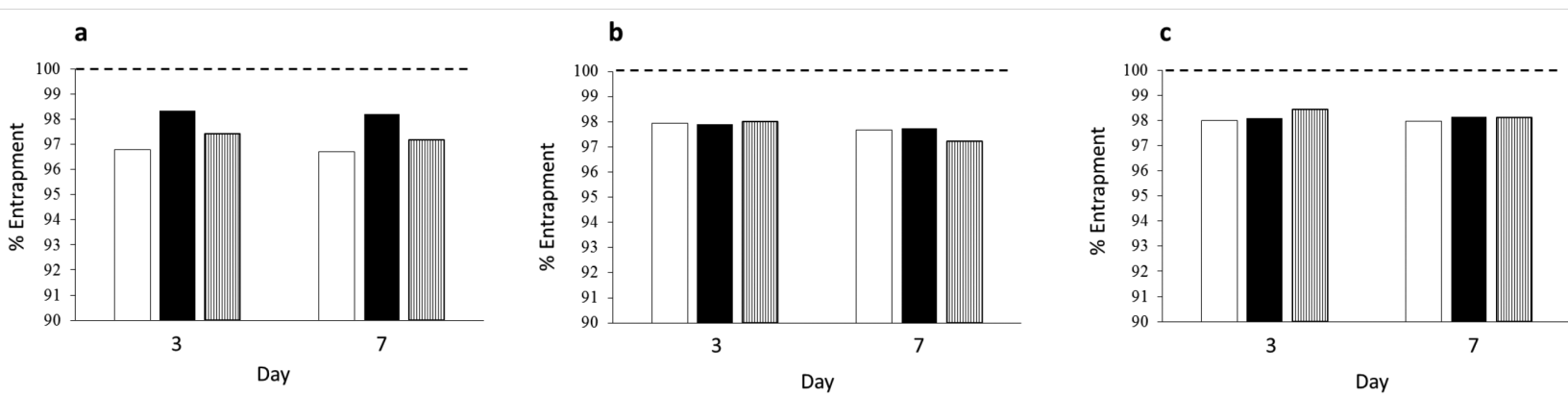

FIGURE 3. Percentage entrapment of niosomes stored for 3 and 7 days at room temperature (a), $4^{\circ} \mathrm{C}$ (b) and $-4^{\circ} \mathrm{C}$ (c). Symbols: Open bar; Formulation 1, closed bar; Formulation 2 and vertically striped bar; Formulation 4. The broken line shows the percentage entrapment at day 0
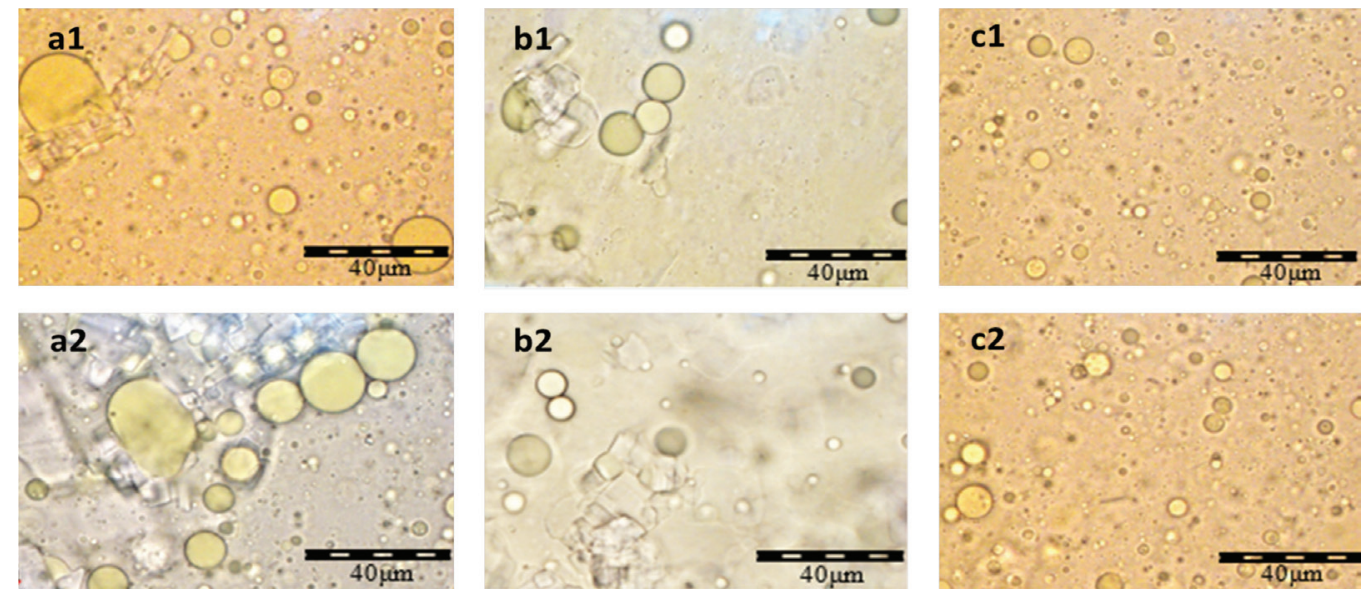

FIGURE 4. Curcumin-loaded niosome for Formulation 1 stored for 3 days at room temperature $(\mathrm{a} 1), 4^{\circ} \mathrm{C}$ (b1), $-4^{\circ} \mathrm{C}(\mathrm{c} 1)$, and for 7 days at room temperature (a2), $14^{\circ} \mathrm{C}(\mathrm{b} 2)$, and $-4^{\circ} \mathrm{C}(\mathrm{c} 2)$ 
bilayer vesicles being thermodynamically unstable and undergone chemical degradation such as oxidation and hydrolysis (Bansal et al. 2013). At $-4^{\circ} \mathrm{C}$, no disrupted vesicles was observed (Figure 4(c1) and 4(c2)), which might be attributed to the rigidization of the vesicles at low temperature. However, this did not reduce the permeability of the drug through the membrane resulting in the decrease of entrapped curcumin similar to niosomes stored at other conditions.

\section{CONCLUSION}

This study showed that niosomes prepared from Formulation 2 with Tween 80 to Span 80 ratio of 1:9 and HLB value 5.37 has superior curcumin EE\% to other formulations. Niosomes synthesized using this formulation also exhibit best stability when stored at room temperature. The results demonstrated that appropriate ratio of Tween 80 to Span 80 was necessary for forming small and stable curcumin niosomes.

\section{ACKNOWLEDGEMENTS}

The authors would like to express their sincere thanks to the Ministry of Higher Education, Malaysia for the financial support under the Fundamental Research Grant Scheme (203/PJKIMIA/6071268).

\section{REFERENCES}

Akhilesh, D., Bini, K.B. \& Kamath, J.V. 2012. Review on span-60 based non-ionic surfactant vesicles (niosomes) as novel drug delivery. Int. J. Res. Pharm. Biomed. Sci. 3: 6-12.

Bansal, S., Aggarwal, G., Chandel, P. \& Harikumar, S.L. 2013. Design and development of cefdinir niosomes for oral delivery. J. Pharm. Bioallied. Sci. 5: 318-325.

Bayindir, Z.S. \& Yuksel, N. 2010. Characterization of niosomes prepared with various nonionic surfactants for paclitaxel oral delivery. J. Pharm. Sci. 99: 2049-2060.

Biswal, S., Murthy, P.N., Sahu, J., Sahoo, P. \& Amir, F. 2008. Vesicles of non-ionic surfactants (niosomes) and drug delivery potential. Int. J. Pharm. Sci. Nanotech.1: 1-8.

Dharashivkar, S., Sahasrabuddhe, S. \& Saoji, A. 2014. Silver sulfadiazine niosomes: A novel sustained release once a day formulation for burn treatment. Int. J. Pharm. Pharmaceut. Sci. 6: 611-616.

Hofland, H.E., Bouwstra, J.A., Verhoef, J.C., Buckton, G., Chowdry, B.Z., Ponec, M. \& Junginger, H.E. 1992. Safety aspects of non-ionic surfactant vesicles: A toxicity study related to the physicochemical characteristics of non-ionic surfactants. J. Pharm. Pharmacol. 44: 287-94.

Hussain, Z., Thu, H.E., Ng, S.F., Khan, S. \& Katas, H. 2017. Nanoencapsulation, an efficient and promising approach to maximize wound healing efficacy of curcumin: A review of new trends and state-of-the-art. Colloids Surf. B. 1: 223-241.

Joung, H.J., Choi, M.J., Kim, J.T., Park, S.H., Park, H.J. \& Shin, G.H. 2016. Development of food-grade curcumin nanoemulsion and its potential application to food beverage system: Antioxidant property and in vitro digestion. J. Food. Sci. 81: N745-N753.
Junyaprasert, V.B., Singhsa, P., Suksiriworapong, J. \& Chantasart, D. 2012. Physicochemical properties and skin permeation of span 60/tween 60 niosomes of ellagic acid. Int. J. Pharm. 423: 303-311.

Lv, G., Wang, F., Cai, W. \& Zhang, X. 2014. Characterization of the addition of lipophilic span 80 to the hydrophilic tween 80-stabilized emulsions. Colloids Surf. A Physicochem. Eng. Asp. 447: 8-13.

Mandal, S., Banerjee, C., Ghosh, S., Kuchlyan, J. \& Sarkar, N. 2013. Modulation of the photophysical properties of curcumin in nonionic surfactant (tween-20) forming micelles and niosomes: A comparative study of different microenvironments. J. Phys. Chem. B. 117: 6957-6968.

Marianecci, C., Di Marzio, L., Rinaldi, F., Celia, C., Paolino, D., Alhaique, F., Esposito, S. \& Carafa, M. 2014. Niosomes from 80 s to present: The state of the art. Adv. Colloid Interface Sci. 205: 187-206.

Nagahama, K., Utsumi, T., Kumano, T., Maekawa, S., Oyama, N. \& Kawakami, J. 2016. Discovery of a new function of curcumin which enhances its anticancer therapeutic potency. Sci.Rep. 6: 30962.

Ratanavaraporn, J., Soontornvipart, K., Shuangshoti, S., Shuangshoti, S. \& Damrongsakkul S. 2017. Localized delivery of curcumin from injectable gelatin/thai silk fibroin microspheres for anti-inflammatory treatment of osteoarthritis in a rat model. Inflammopharmacology 25(2): 211-221.

Ruckmani, K., Jayakar, B. \& Ghosal, S.K. 2000. Nonionic surfactant vesicles (niosomes) of cytarabine hydrochloride for effective treatment of leukemias: Encapsulation, storage, and in vitro release. Drug Dev. Ind. Pharm. 26: 217-222.

Rungphanichkul, N., Nimmannit, U., Muangsiri, W. \& Rojsitthisak, P. 2011. Preparation of curcuminoid niosomes for enhancement of skin permeation. Pharmazie. 66: 570575.

Shahiwala, A. \& Misra, A. 2002. Studies in topical application of niosomal entrapped nimesulide. J. Pharm. Pharmaceut. Sci. 5: 220-225.

Tavano, L., Alfano, P., Muzzalupo, R. \& De Cindio, B. 2011. Niosomes vs microemulsions: New carriers for topical delivery of capsaicin. Colloids Surf. B Biointerfaces. 87: 333-339.

Xu, Y.Q., Chen, W.R., Tsosie, J.K., Xie, X., Li, P., Wan, J.B., He, C.W. \& Chen, M.W. 2016. Niosome encapsulation of curcumin: Characterization and cytotoxic effect on ovarian cancer cells. J. Nanomater. 2016: Article ID. 6365295.

Yoshioka, T., Sternberg, B. \& Florence, A.T. 1994. Preparation and properties of vesicles (niosomes) of sorbitan monoesters (span 20, 40,60 and 80) and a sorbitan triester (span 85). Int. J. Pharm. 105: 1-6.

Masrina Mohd Nadzir*, Tan Wei Fen,

Abdul Rahman Mohamed \& Siti Farhana Hisham

School of Chemical Engineering, Engineering Campus

Universiti Sains Malaysia,

14300 Nibong Tebal, Pulau Pinang

Malaysia

Siti Farhana Hisham

Biomedical Materials Section,

Advanced Materials Research Centre 
AMREC, SIRIM Berhad

Lot 34, Jalan Hi-Tech 2/3, Kulim Hi-Tech Park 09000 Kulim, Kedah Darul Aman

Malaysia
*Corresponding author; email: chmasrina@usm.my

Received: 26 June 2016

Accepted: 27 March 2017 